Etikonomi

Volume 15 (1), April 2016

P-ISSN: 1412-8969; E-ISSN: 2461-0771

Page 19 - 30

\title{
THE IMPACT OF ROA, BOPO, AND FDR TO INDONESIAN ISLAMIC BANK'S MUDHARABAH DEPOSIT PROFIT SHARING
}

\author{
Laila Mugi Harfiah, Atiek Sri Purwati, Permata Ulfah \\ Universitas Jenderal Soedirman \\ lailamugih@gmail.com, aisyaatiek@yahoo.co.id,permataulfah@yahoo.com
}

\begin{abstract}
.
This study aims to determine the effect of profitability ratio (ROA) the cost-revenue ratio (BOPO) and financing to deposit ratio (FDR) toward profit sharing of time deposit mudharaba in Islamic banking in Indonesia. This research is a quantitative study using heading the entire population of Islamic banks in Indonesia and the sample was selected using purposive sampling method. Samples were obtained at 7 Islamic banks and research data in the form of quarterly reports Islamic Banks 2011-2014 period. The analysis namely with the used is a multiple linear regression analysis. The results of the data analysis showed that ROA, BOPO and FDR significant positive effect on the level of profit sharing of time deposit mudharaba. Is divided in changes in the rise and fall rate for the time deposits mudharaba can be explained 47.9 percent by ROA, BOPO and FDR, while 52.1 percent can be explained by other variables not examined.
\end{abstract}

Keywords: Profit Sharing; ROA; BOPO; FDR

\begin{abstract}
Abstrak.
Penelitian ini bertujuan untuk mengetahui pengaruh rasio profitabilitas (ROA) rasio biaya (BOPO) dan Pembiayaan to Deposit Ratio (FDR) terhadap bagi hasil deposito mudharabah dalam perbankan syariah di Indonesia. Penelitian ini merupakan penelitian kuantitatif dengan menggunakan bank Islam di Indonesia dengan sampel yang dipilih dengan metode purposive. Sampel diperoleh sebanyak 7 bank syariah dan data penelitian dalam bentuk laporan triwulanan bank Islam periode 2011-2014. Analisis yang digunakan adalah analisis regresi linier berganda. Hasil analisis data menunjukkan bahwa ROA, BOPO dan FDR berpengaruh positif signifikan terhadap tingkat bagi hasil deposito mudharabah. Tingkat variasi perubahan naik turunnya deposito mudharabah dapat dijelaskan sebanyak 47,9 persen oleh ROA, BOPO dan FDR, sementara 52,1 persen dijelaskan oleh variabel lain yang tidak diteliti.
\end{abstract}

Kata Kunci: Bagi Hasil; ROA; BOPO; FDR

Received: December 21, 2015; Revised: February 7, 2016; Approved: February 28, 2016 
The Impact of ROS, BOPO, and FDR to Indonesian Islamic Bank's Mudharabah Deposit

Laila Mugi Harfiah, Atiek Sri Purwati, Permata Ulfah

\section{INTRODUCTION}

Islamic bank formed in Indonesia due to the desire to avoid the practice of riba, which is located in the system of interest. The more aware of Indonesian society to apply religious principles in all aspects of life especially in economy aspect encouraging them to seek the solutions to fulfill their needs both in terms of investment or capital compliance with halal way and free from the practice of interest. In other words the presence of Islamic bank as one of the alternative solution to the contradiction question of conventional bank with riba, so that the fundamental difference between conventional and Islamic banking is the prohibition of interest rate system that embraced by conventional banks. In operational activities, Islamic bank based on Islamic law, profit sharing system.

Riba is additional, both in the trading transaction or loan in falsehood or contrary to the Islam principles. Riba or interest is forbidden because in the language means ziyadah or additional (Antonio, 2001). On Islamic banking, the process of gathering funds is done with two principles such as: retention (wadi'ah) and investment (mudharabah). The principle of the wadi'ah means the bank $\mathrm{r}$ eceive a retention from the client and fully responsible to hold. Customers have the right to take every moment, according to applicable terms. This wadi'ah principle applies on demand deposit wadi'ah and saving deposit wadi'ah. While the principle of mudharabah which is based on the principle of profit sharing according to the PSAK No. 105 paragraph 4 is business cooperation regulation between the two parties in which the first party (owner fund) provides all funds while the second party (fund managers) acting as management, and profit shared among them according to the agreement, and financial loss only covered by the owner. In this case, the bank has two roles at the time of gathering funds (funding) bank as the fund managers or mudharib, while at the time of the transfer of funds (financing) as the owner of the fund or shahibul maal. Mudharabah principle applies on saving deposit mudharabah products and time deposit mudharabah.

Outlook of Islamic banking, January 2015 stated that total third party funds for the wadi'ah was Rp30.329 trillion, while in the form of savings for 
mudharabah was Rp50.080 trillion and mudharabah deposit was Rp130.352 trillion (Bank Indonesia, 2015). The amount of mudharabah deposit is greater than the current wadi'ah and mudharabah savings, this shows that the mudharabah deposit, which is based on profit sharing, is quite attracted by the client. The development of Islamic banking in Indonesia is more rapid. The existence of Islamic banking is began as the first Islamic bank in Indonesia in 1992 and with the enactment of Law No. 7 Year 1992 regarding banks that then amended with Law No. 10 Year 1998, until 2015 has recorded as many as 12 Islamic General Bank, 22 Islamic Business Units, and 164 Islamic Financing Bank for the Society with total office reached 2,944 offices. In terms of assets, it is occurred a significant increase in the last 5 years, from Rp97.519 trillion to Rp263.468 trillion in 2015 (Bank of Indonesia, 2015).

The more rapid development of Islamic banking in Indonesia, competition among Islamic bank for improving the quality of services in order to attract the customers is also increasing high. Various studies have found that the behavior of the customer in choosing Islamic bank driven by benefit factors. The research that has been done by Husnelly (2003) and Mangkuto (2005) also stated that the factors that becoming a consideration in society to invest in Islamic bank is the profit sharing factor. There are a lot of factors that can influence the profit sharing, such as macroeconomic variables (Al Arif, 2011), interest rate (Al Arif, 2010) and financial ratios.

The great or small of profit sharing on mudharabah contract depends on bank income (Antonio, 2001). Some of the financial ratios that can be used as consideration in assessing the bank income are the ratio of profitability, ROA, BOPO ratio and liquidity ratio (FDR). This research tied to test the effect of the ratio of profitability ROA, BOPO ratio and liquidity ratio (FDR) to the level of mudharabah deposit profit sharing due to the inconsistency results.

\section{METHOD}

This is a quantitative research using financial data of Islamic General Bank in Indonesia. The population of this research is the Islamic General Bank in 
The Impact of ROS, BOPO, and FDR to Indonesian Islamic Bank's Mudharabah Deposit

Laila Mugi Harfiah, Atiek Sri Purwati, Permata Ulfah

Indonesia from 2011 to 2014 year period. A sample of this research is determined by the method of purposive sampling with the criteria as follows:

a. Islamic General Bank which is consistence in operating between 2011 and 2014.

b. Islamic General Bank which publish the Islamic quarterly financial report from 2011 to 2014.

c. Presents data regarding ROA, BOPO and FDR during the period 2011-2014.

Multiple linear regression tests the influence of the independent variables against the dependent variables. In multiple linear regression analysis, a number of free variables used more than one (Suliyanto, 2011). This analysis is used to test the hypothesis with the regression equation as follows:

$$
Y=\alpha+\beta_{1} \cdot x_{1}+\beta_{2}, x_{2}+\beta_{3}, x_{3}+e
$$

Where:

$$
\begin{aligned}
& \mathrm{Y}=\text { Mudharabah profit sharing } \\
& x_{1}=\text { ROA } \\
& x_{2}=\text { BOPO } \\
& x_{3}=\text { FDR } \\
& \text { e }=\text { error }
\end{aligned}
$$

\section{Hypothesis test (t)}

This test is done to determine the influence of each of the independent variables against the dependent variables.

\section{a. Formulate the hypothesis}

1) Ho1: $\beta 1=0$

ROA did not influence the level of for the results of mudharabah deposit.

Ha1: $\beta 1 \neq 0$

ROA has a positive effect to the level of mudharabah deposit profit sharing.

2) Ho2: $\beta 2=0$

BOPO does not affect to the level of mudharabah deposit profit sharing. Ha2: $\beta 2 \neq 0$

BOPO has a negative effect on the level of mudharabah deposit profit sharing. 
3) Ho3: $\beta 3=0$

FDR did not affect to the level of mudharabah deposit profit sharing. Ha3: $\beta 3 \neq 0$

FDR has a positive effect on the level of mudharabah deposit profit sharing.

\section{b. Hypothesis Testing Criteria}

The level of significance $(\alpha)=0.05$

Degree of Freedom $=(\mathrm{n}-\mathrm{k})$

$\mathrm{H}_{01}$ accepted if: $\mathrm{t}$-test $\leq \mathrm{t}$-table, or $\mathrm{Sig}>\alpha$

$\mathrm{Ha}_{1}$ accepted if: t-test $>\mathrm{t}$-table, or $\mathrm{Sig} \leq \alpha$

\section{DISCUSSION}

This research population is the Islamic banking in Indonesia from 2011 to 2014 period. The sample of Islamic General Bank that was taken used the purposive sampling method. Based on the method, obtained 7 Islamic General Bank in four years in the form of quarterly reports, so that the total 112.

\section{Analysis of descriptive statistics}

The lowest value of dependent variables mudharabah deposit profit sharing is $1.23 \%$ owned by Muamalat Bank of Indonesia in the first quarter of 2013 and the highest value mudharabah deposit profit sharing is $8.40 \%$ Bukopin Islamic Bank on the fourth quarter of 2014. According to Monetary Policy Review Bank of Indonesia in 2014, deposit rate conventional bank is $8.24 \%$, this shows that the level of the results given to depositors higher compared to the deposit rate. While for the average value mudharabah deposit profit sharing on Islamic General Bank in Indonesia between 2011 and 2014 was 4.0055\% (table 5), is lower compared to the average deposit rate conventional banks in 2011-2014 period amounting 6.73\% (Bank Indonesia, 2011-2014).

The first independent variable is ROA. The results of the analysis of descriptive statistics show that the lowest value for the ratio ROA is $0.01 \%$ owned by the Islamic Bank Rakyat Indonesia in the second quarter of the year 2014 and the highest value of 2,19\% owned by Islamic Bank Mandiri in the fourth quarter in 2012. According to Bank Indonesia Regulation No. 9/1/PBI/2007 about 
The Impact of ROS, BOPO, and FDR to Indonesian Islamic Bank's Mudharabah Deposit

Laila Mugi Harfiah, Atiek Sri Purwati, Permata Ulfah

Assessment System of General Bank Soundness based on Islamic Principles, the Islamic Bank Rakyat Indonesia ROA is located on stage 4 and the Islamic Bank Mandiri ROA is in stages 1 . Whilst the value of the average ROA of the Islamic Bank Indonesia from 2011 to 2014 was $0.6420 \%$ in stages 3, it means that the average financial performance of Islamic General Bank in Indonesia is good enough.

The second independent variable is the BOPO. The results of the descriptive statistics analysis show that the lowest value for the ratio of BOPO is $67.98 \%$ owned by Islamic Bank Negara Indonesia in the first quarter in 2011 and the highest value of $102.33 \%$ owned by the Islamic Bank Rakyat Indonesia in the first quarter in 2011. According to Bank Indonesia Regulation No. 9/1/PBI/2007 about Assessment System of General Bank Soundness based on Islamic Principles, Islamic Bank Negara Indonesia BOPO is located on stage 1 and the ratio of Islamic Bank Rakyat Indonesia BOPO is located on stage 5 . While the value of the average BOPO ratio in the Islamic General Bank in Indonesia form 2011 to 2014 was $84.8363 \%$ in stages 2, means Islamic bank in Indonesia has been efficient in running the activities of operations.

The third independent variable is FDR. The results of the descriptive statistics analysis show that the lowest value for the ratio of the FDR is $69.89 \%$ owned by the Islamic Bank of West Java Banten in the fourth quarter in 2011 and the highest value of $135.29 \%$ also owned by the Islamic Bank of West Java Banten in the first quarter in 2011. Based on the terms of the Bank of Indonesia, Islamic Bank of West Java Banten in the fourth quarter in 2011 has an FDR value under $110 \%$ so that it is good, while in the first quarter in 2011, an FDR value exceeds $110 \%$ then the value of the FDR worse. The average value of the FDR on the Islamic General Bank in Indonesia from 2011 to 2014 was 99.7222\% means the value of the Islamic General Bank in Indonesia has been good.

\section{The Classical Assumption Test}

Based on the data analysis, it can be known that the value of 1.133 Kolmogorov-Smirnov and Asymp. value. Sig. (2-tailed) is 0.154. This result indicates that the model meets normality test. 
Based on the summary of the results in table 1, it can be known that all of the independent variables which ROA, BOPO and FDR have values of tolerance > 0.10 and VIF value $<10$, which means that is no correlation among them.

\section{Table 1. Multi-co-linearity Test}

\begin{tabular}{ccc}
\hline The variables & Tolerance & VIF \\
\hline ROA & 0,678 & 1,474 \\
BOPO & 0,697 & 1,434 \\
FDR & 0,949 & 1,053 \\
\hline
\end{tabular}

Based on the summary of the results in table 2, it can be seen that the value of the significance of each of the variables $>\alpha(0.05)$ so it can be concluded that no symptoms heteroscedasticity in regression model.

Table 2. Heteroscedasticity Test

\begin{tabular}{cc}
\hline The variables & Sig \\
\hline ROA & 0,874 \\
BOPO & 0,260 \\
FDR & 0,384 \\
\hline
\end{tabular}

Based on the analysis of the data on the attachment 2, can be known that the value of the Asymp. value. Sig. (2-tailed) is 0.569 .

\section{Multiple Regression Analysis}

The test of direct effect from the independent variables (ROA, BOPO and FDR) against dependent variables in this research uses multiple regression analysis. Based on the results, it was obtained a summary of the results as follows:

Table 3. Multiple Regression Analysis

\begin{tabular}{|c|c|c|c|c|c|c|c|}
\hline No & \multicolumn{3}{|c|}{ variables } & Coefficient & T-test & T-table & Sig.t \\
\hline 1 & \multicolumn{3}{|c|}{ ROA (X1) } & 2,843 & 9,293 & 1,6587 & 0,000 \\
\hline 2 & \multicolumn{3}{|c|}{ BOPO (X2) } & 0,132 & 7,961 & 1,6587 & 0,000 \\
\hline 3 & \multicolumn{3}{|c|}{ FDR (X3) } & 0,036 & 3,495 & 1,6587 & 0.001 \\
\hline \multicolumn{2}{|c|}{ Constant } & $=$ & $-12,616$ & & & & \\
\hline \multicolumn{2}{|c|}{ Adjusted $\mathrm{R}^{2}$} & $=$ & 0,479 & & & & \\
\hline \multicolumn{2}{|c|}{$\mathrm{F}_{\text {test }}$} & $=$ & 35,062 & & & & \\
\hline \multicolumn{2}{|c|}{$\mathrm{F}_{\text {table }}$} & $=$ & 2,690 & & & & \\
\hline \multicolumn{2}{|l|}{$\mathrm{F}_{\text {sig. }}$} & $=$ & 0,000 & & & & \\
\hline
\end{tabular}


The Impact of ROS, BOPO, and FDR to Indonesian Islamic Bank's Mudharabah Deposit

Laila Mugi Harfiah, Atiek Sri Purwati, Permata Ulfah

Based on based on the data in Table 3, it can be made multiple regression equation as follows :

$$
Y=-12,616+2,843(\mathrm{ROA}+0,132(\mathrm{BOPO})+0,036(\mathrm{FDR})+\mathrm{et}
$$

\section{The Goodness of Fit Test}

\section{F Test}

Based on the table 3, it can be shown that F-test value was greater than Ftable value $(35,062>2.69)$ and value of $F_{\text {sig }}$ was smaller than $\alpha(0,000<0.05)$. Thus can be stated that the regression model that formed stated suitable or fit.

\section{Coefficient Determination}

Based on the statistics result, it is obtained the value of Adjusted $\mathrm{R}^{2}$ is 0,479 . The coefficient shows that $47.9 \%$ variation of mudharabah deposit profit sharing can be explained by ROA, BOPO and FDR, while $52.1 \%$ is explained by other variables which have been not examined.

\section{Hypothesis Testing}

The results of the hypothesis test 1 , it is known that value of t-test ROA variable is greater than the value of t-table $(9,293>1,6587)$ and value of sig. $t$ is smaller than the value $\alpha(0,000<0.05)$ with the direction of the positive coefficient. From the results it can be concluded that ROA variables have positive significant impact on the level of mudharabah deposit profit sharing, thus the hypothesis $1\left(\mathrm{H}_{1}\right)$ is accepted.

The results of the hypothesis test 2, it is known that variable BOPO t-test value is greater than the value of t-table $(7,961>1,6587)$ and value of sig. $t$ is smaller than the value $\alpha(0,000<0.05)$ with the direction of the positive coefficient. From the results it can be concluded that the variables BOPO significant positive effect of the level of mudharabah deposit profit sharing, thus the hypothesis $2\left(\mathrm{H}_{2}\right)$ is accepted.

The results of the hypothesis test 3 , it is known that variable t-test FDR value is greater than the value of t-table $(3,495>1,6587)$ and value of sig. $t$ is smaller than the value $\alpha(0.001<0.05)$ with the direction of the positive coefficient. It can be concluded that FDR variables have positive significant impact 
on the level of mudharabah deposit profit sharing, thus the hypothesis $3\left(\mathrm{H}_{3}\right)$ is accepted.

This study result shows that ROA has a significant positive effect to the mudharabah deposit profit sharing. This means that the higher the ROA, then the higher mudharabah deposit profit sharing. This result is in line with the other research that has been done by Rahayu (2014). It stated that ROA has a positive effect of mudharabah deposit profit sharing. The ROA used to measure the ability of the bank management achieving benefit in overall (Dendawijaya, 2005). The high ROA describes the ability of bank in getting a high gain (Fahmi, 2012). This result is also in line with the theory of stewardship which stated that the steward will behave cooperative learning by improving the performance of the company that can give satisfaction to principal (Donaldson and Davis, 1991).

The results of the study showed that BOPO has a significant positive effect to mudharabah deposit profit sharing. This means that the higher the BOPO, then the higher of mudharabah deposit profit sharing. This result is contrary to the theory that stated that the efficiency of Islamic bank in cost can produce high income. BOPO calculations used to know the greatness of the costs incurred by the bank to earn income as well as to measure the efficiency of bank activity (Rivai and Arifin, 2010). According to Dendawijaya (2005) BOPO is a ratio to measure the level of efficiency and the ability of bank to conduct the operational activities. This result is in line with Gundari (2015) which showed that the BOPO has a positive effect to mudharabah deposit profit sharing. Increasing of BOPO value can be caused by the multitude of operational costs that are issued for the expansion of the office network and collect third party funds through the promotion while the revenues remain. This result is also in line with the theory of stewardship which stated that the steward will behave cooperative learning by improving the performance of the company that can give satisfaction to principal (Donaldson and Davis, 1991). Although the operational costs that are issued are high, the bank still tries to give a high of mudharabah deposit profit sharing to the customers. 
The Impact of ROS, BOPO, and FDR to Indonesian Islamic Bank's Mudharabah Deposit

Laila Mugi Harfiah, Atiek Sri Purwati, Permata Ulfah

The results of this study show that FDR significant has a positive effect of the level to the mudharabah deposit profit sharing. This means that the higher the FDR, then the higher of mudharabah deposit profit sharing. This result is in line with Gundari (2015) which showed that FDR has a positive effect to mudharabah deposit profit sharing. The higher FDR then the ability of bank in distributing the funds is better so that the revenues that are received is also higher (Muhammad, 2005). This result is also in line with the theory of stewardship which stated that the steward will behave cooperative learning by improving the performance of the company that can give satisfaction to principal (Donaldson and Davis, 1991).

\section{CONCLUSION}

The theory is explained that when the ROA value is high so financial performance is better because it is able to gain advantage through the usage of the asset owned. Then ROA level increase and the profit sharing that customer received is also increase. The smaller of BOPO means more efficient operational burden that issued by the bank. However, in this research, the higher BOPO thus increasing the level for the results obtained by the client. When revenue obtained high bank then the level for the result which is received by the client is also the higher. Therefore, when FDR increased then the level for the result which is received by the client also increased.

\section{REFERENCES}

Al Arif, M. N. R. (2010). Tingkat Suku Bunga Bank Konvensional dan Pengaruhnya Terhadap Penetapan Persentase Bagi Hasil di Bank Syariah (The Effect on Conventional Banks Interest Rate to ProfitSharing Yield in Islamic Banks). Jurnal Dialog, Vol. XXXIII, Number 69, July 2010, pp. 80-93.

Al Arif, M.N.R. (2011). The Effects of Macroeconomic Variables on Profit-Sharing Yield Pricing. Economic Journal of Emerging Markets, Vol. 3 (3), Dec. 2011, pp. 235-244. 
Antonio, M.S. (2001). Bank Syariah dari Teori ke Praktik (Islamic bank from theory to practice). Jakarta: Gema Insani Press.

Dendawijaya, L. (2005). Manajemen Perbankan (Banking management). Bogor: Ghalia Indonesia.

Ghozali, I. (2013). Aplikasi Analisis Multivariat dengan Program IBM SPSS 21 (Multivariat Analysis application with IBM SPSS Program 21). Semarang: BP Universitas Diponegoro.

Husnelly. (2003). Analisis Faktor-faktor yang Mempengaruhi Investasi Dana Masyarakat Pada Bank Syariah: Studi Kasus BSM (Analysis of the investment that Infuenced public funds on Islamic bank: Case Study on BSM). (Unpublished Thesis). Jakarta: Universitas Indonesia

Isna A \& Sunaryo. (2012). Analisis Pengaruh Return on Asset, BOPO, dan Suku Bunga Terhadap Tingkat Bagi Hasil Deposito Mudharabah pada Bank Umum Syariah (Analysis of the influence of the Return on Asset, BOPO, and interest rate of mudharabah deposit profit sharing on Islamic General Bank.) Jurnal Ekonomi dan Bisnis, Vol. 11 No. 1, pp. $29-42$.

Mangkuto, I.J. (2005). Pengaruh Tingkat Suku Bunga Deposito Bank Konvensional dan Tingkat Pendapatan Deposito Mudharabah Terhadap Pertumbuhan Deposito di Bank Muamalat (The influence of the interest rate on the deposit facility conventional banks and Deposit Mudharabah income levels of the growth of Deposit in Bank Transactions). Jurnal Ekonomi Keuangan dan Bisnis Islam, Vol. 1 No. 1, pp. 31-40.

Muhammad. (2005). Manajemen Bank Syariah (Shariah Bank Management). Yogyakarta: UPP AMP YKPN.

Rivai, V. \& A. Arifin. (2010). Islamic Banking: Sebuah Teori, Konsep, dan Aplikasi (Islamic Banking: a theory, the concept and applications). Jakarta: PT. Bumi Aksara.

Salman, K.R. (2012). Akuntansi Perbankan Syariah: Berbasis PSAK Syariah (Islamic Banking Accounting: Based on Syariah PSAK). Padang: Akademia Permata

Sekaran, U. (2008). Metodologi Penelitian (Research Methodology for Business). Jakarta: Salemba Empat. 
The Impact of ROS, BOPO, and FDR to Indonesian Islamic Bank's Mudharabah Deposit

Laila Mugi Harfiah, Atiek Sri Purwati, Permata Ulfah

Suliyanto. (2005). Analisis Data dalam Aplikasi Pemasaran (Data Analysis in Marketing Applications). Bogor: Ghalia Indonesia.

Suliyanto. (2011). Ekonometrika Terapan (Applied Econometrica: Theory and applications with SPSS). Yogyakarta: CV Andi Offset. 